\title{
INDETERMINACY, INDIGENEITY, PEER REVIEW AND THE MIND-BODY PROBLEM
}

\section{BACKGROUND}

Declining funding over the past decade for tertiary education in South Africa resulted in tens of thousands of disillusioned students engaging in national protests during 2015 and 2016. ${ }^{1}$ The grievances were many, but included de-colonisation of curricula, together with a call that linked peer review to perceived forms of Eurocentric gatekeeping. This paper examines this claim in the context of assertions of "African ways of making sense" in relation to post-Enlightenment philosophy.

For the purposes of this analysis, indigeneity involves the contemporary performance of self by specific groups alienated from Western epistemologies, procedures and practices. These intellectual constituencies often claim 'epistemic injustice' in peer reviewing, and their response is to demand a restoration of relations with the group's imagined past. Given that the Indigene's historically unacknowledged claim to political primacy casts the constitutionality of all frameworks of relation in crisis, what are appropriate bases for peer review? My analysis examines how the relationships of self-proclaimed Indigenous African communities function in a contemporary era of ideological concern conceived largely through Western practices. ${ }^{2}$

Whiteness, de-colonisation, de-Westernisation, indigenisation, transformation and epistemic resistance are a few recent terms, some more intellectually coherent than others, generated from the academic peripheries (both geographical and epistemological) with a view to challenging Western epistemological Enlightenment assumptions. These assumptions have been in some instances described as "epistemic injustices." Injustice in this sense occurs when someone feels wronged in their capacity as a knower. ${ }^{3}$ A recurring example is when article submissions are rejected or returned for substantive revision because they are written in styles that differ from the 'Western' norm. It is argued that when applied instrumentally, this norm exerts a deflationary and even discrediting effect on the authors concerned. However, when an argument is based on the proposition "you are what you know," it becomes difficult to engage, critique or refute. 
In approaching this vexed topic, let me start with three quotations about the idea of transformation - which, in the South African context, is often linked with the rhetoric of indigenous knowledge systems (IKS) that were largely suppressed and regarded as superstition during the colonial era. The first is by Jonathan Jansen, at the time vice-chancellor of the University of the Free State, a formerly white, Afrikaans-speaking institution riven with racial tensions during the early postapartheid era. Jansen, the university's first black vice-chancellor, observed that the "new racial nationalists are impatient and want short cuts ... [U]niversities must be challenged to deal with the very real problem of racial gatekeeping and the spectacular lack of imagination in slowly but systematically building the next generation of especially black and women professors." 4

Second, Nomalanga Mkhize, a lecturer in history at Rhodes University, points out that

[s]ome critics opposed to curriculum transformation confuse "curriculum decolonisation" with "curriculum displacement". Some of the most reactionary critics within the university sector are, on the one end, conservative academics who fear the demotion of the European scholarly canon. On the other end, are the so-called left wing radicals who interpret transformation as a "narrow racial project" that is driven by "identity politics". ${ }^{5}$

Third, according to Belinda Bozzoli, the liberal Democratic Alliance's shadow minister for Education, a previous deputy vice-chancellor at the University of the Witwatersrand and a sociologist, "the word 'transformation' fails utterly to capture the depth of the problem of University staffing (which has failed to keep up with student enrolment). The meaningless and authoritarian word, which can mean what you want it to mean, in this case carries the implication that there has been some sort of conspiracy, racial gatekeeping or politically incorrect neglect by universities." 6

These statements about transformation are attempting to take the discussion beyond identity politics, which in post-liberation South Africa officially continues with the discredited apartheid categories of 'African' (black, South African), 'white' (of European descent), 'coloured' (mixed race) and 'Asian' (Indian). These racial categories continue to regulate access to social resources, identity and job prospects. ${ }^{7}$ The general discourse that these three commentators seek to address is well articulated by many critics who argue that the relocation of the racial boot from one foot to the other has yet to occur in any significant way.

The victimological framework that has been created generates recurring complaints at South African meetings about "discrimination in publishing," among other alleged exclusionary practices, all deemed to be irrevocably racist. These complaints hinge on the perceived lack of racial and gender representation, a lack of 'transformation,' and perceptions about the use of peer review as censorship. ${ }^{8}$

My objective in approaching this highly vexed issue is not to take sides between the two extremes - characterised on the one hand by empirically based classical (Western)-style science, regulated by notions of objectivity and absolute, knowable truth; and, on the other, an alter-ego inquiry that recognises its own subjectivity, sense of being and researcher position. My goal goes beyond the phenomenological by delving into ontological issues that inquire how different epistemic cultures make sense by navigating different Subject-Object relationships, or what might be termed by some as essentialist modes of thought. Given these complexities and contradictions, solutions are 
not on offer here. Rather, my aim is to identify and confront the issues, however difficult they may be, without painting readers into one corner or another.

When linked to identity politics and the occult, the clash of paradigms often underpins the epistemological tectonics described below, and as much as I have tried to avoid a tendency to African exceptionalism, I cannot guarantee success. My approach is primarily interpreted through my own practice as a journal editor and author, from which my examples are drawn. Learning what can be learned from the extremes is perhaps all that one can accomplish in terms of managing the peer-review process across different paradigms, antagonistic ontologies and epistemological communities.

\section{RACE, IDENTITY AND HEMISPHERICAL DOMINANCE}

In South Africa, common sense presumes that racism is present wherever race-based demographic proportionality is absent. ${ }^{9}$ Whites, of course, are intrinsically associated with Europe and European colonisation. In questioning epistemological hemispherical dominance, Pearl Sithole writes that “[ $\mathrm{f}]$ ar from maintaining equality between reviewer and reviewed, the peer review process is dominated by scholars allied to Western models of knowledge production, who use their 'gateway' positions to marginalise and discourage African schools of thought." ${ }^{10}$ Sithole further asserts that local or indigenous knowledge is (negatively or derisively) equated with "subjective" analysis, and that objectivity is an often inappropriate Western export that defines who gets published. ${ }^{11}$ "Viewpoint discrimination" and asymmetrical representation on international editorial boards of scholars based in developing countries are additional concerns. ${ }^{12}$ In psychology, for example, 96 percent of examples in journal articles are sourced from countries that constitute only 12 percent of the global population. These 12 percent findings are then often inappropriately generalised across the human population as a whole. ${ }^{13}$

This article deals with paradigmatic, ontological and ideological issues that result in what Willard V O Quine calls the "indeterminacy of radical translation," the purportedly different grounds for practice through which interpreters make sense of their linguistically different, often incompatible, ontological worlds. ${ }^{14}$ Discrimination is perceived within both realms by aggrieved authors. The concept of 'indeterminacy' is used to connote the sense of uncertainty, instability and lack of agreement between different meanings. Quine argues that there can be multiple translations of a single sentence, resulting in different meanings in parts or wholes of sentences.

For example, earlier drafts of this paper (now published in Junctures) submitted for publication and circulated for comment have starkly highlighted the kinds of indeterminacies at work. Reviewer comments for the South African Journal of Science (SAJS), where an earlier version of this paper was first submitted, ranged from "philosophically sophisticated" on the one hand to "condescending" on the other - the latter reviewer vigorously denied the role of structures, recruitment, methods, outcomes and institutional ideologies in influencing research practice. Another reviewer accused me of "intellectual dereliction" for articulating (with the help of my Zimbabwean colleague Nyasha Mboti) a structurationist perspective that seeks to understand the discrimination that so many Africans feel with regard to the institutional cultures, policies and managerial procedures in which they feel trapped (feelings evocatively described by Sithole below). 
The idea that knowledge (or, in the positivist framework, 'Truth') could be relational, constructed and negotiated between different scientific discursive (and often, faith-led) communities is hard to fathom when the critic is embedded in the data-led hegemonic scientistic discourse of validity, reliability and objectivity, and/or monological reasoning. In transgressing this framework and adopting one like 'cultural studies,' one reviewer pondered how to assess "scholarly rigour despite these different world views." Added to the paradigmatic fog is the question of identity politics - some argue that discrimination resides in the machinations of senior academics and white (and sometimes black) men who personally deny access to emergent scholars and non-Western viewpoints.

Research Africa, ${ }^{15}$ for example, reported that senior African academics stand accused of monopolising South African journals, impeding young researchers from access. Among those who spoke out against this exclusion at the Southern African-Nordic Centre Third Bi-Annual International Conference (Johannesburg) was Howard Rachman, research director of the University of Limpopo. Referring to an article in the Sunday Times, Rachman is reported to have told delegates at a session on socially responsive Africa-centred research that "[t]here is a mafia control of publishing houses" (personal communication, 26 January 2011). Senior academics "hog" journals, the biochemist claimed. "Some people publishing in the journals are also on the editorial board and don't permit entry into these journals. This makes it difficult for young researchers to publish." He added that international publishers often dismissed manuscripts from African scholars as being unrelated to current academic debates. "They say they don't conform to Western norms and expectations."

My own argument, however, is that the issues run much deeper than such impressionist claims about normativity. We need to examine not only the disaffected feelings of a growing constituency of increasingly vocal black academics, but also ask how the knowledge project is actually managed. In addition, we need to examine how and why Western concepts of science and philosophy continue to dominate the South African academic milieu in the face of the massive class, ontological and cultural changes that have affected the academy since the mid-1990s.

The apportioning of "blame," as one reviewer wrote of a much earlier, shorter commentary on peer review that I submitted a decade ago, also to SAJS, is not my intention. Neither do I want to justify my own class and racial determinations, nor my identity. My objective is to bridge ways of thinking and doing, and in the process to address the vexed issue of the practice of peer review, which itself is often a contradictory negotiation of what is finally agreed upon as the ultimate opinion, itself a dynamic and never-ending quest. ${ }^{16}$

Paradigm clash is the issue. Unusually for a cultural studies scholar, my own research draws on both positivist (including statistical) and interpretivist (constructionist) paradigms; thus the ambiguities and contradictions so perceptively identified by one of my critics will no doubt be evident in this analysis also. But, as this reviewer concluded, "the problem must be confronted and debated." Thanks to this initial reviewer of the shorter draft originally submitted to SAJS in 2007, I have thoroughly revised this version and, by applying an autoethnographic methodology, I hope to be able to speak to scholars across antagonistic paradigms and researcher positions. As already admitted, agreed-on solutions cannot be anticipated.

Questions of evidence, data and findings are characteristic of objective social science. By contrast, the 'lived' methods approach often applied in cultural studies work, which sometimes rejects the value of data altogether, ${ }^{17}$ is exemplified by Nyasha Mboti, who argues that according to this 
approach there are no findings to be found: "Dialogue fails as long as objectivity shields the researcher from the researched's gaze. Too often, 'scientific' research speaks-to without listeningto. Research 'findings,' also, are monologic because it is the researched who has been found, never the neutral(ised) researcher. Prodigality means that we have, finally, outgrown our own objectivity as researchers." ${ }^{18}$

In contesting what is assumed to be a Western scientific monologue, Sithole's book, which I invoke as a brief case study, reproduces as chapters examples of three of her unrevised rejected articles. Appended to each are the peer review reports and brief author-editor correspondence. Sithole expects readers to make up their own minds on the data (articles) and evidence (peer-review reports) presented, along with her introduction and conclusion.

Are editors, editorial boards and publishing houses really co-conspirators?

\section{SOUR GRAPES OR VALID ACCUSATION?}

The argument set out below draws on my own experience of editing and publishing in academic journals since the mid-1970s, as an author in many languages in translation, and as an editorial board member for over 30 titles globally, including many published within Africa itself. While sympathising with emergent scholars trying to start a publishing career, I do not agree that editorial boards a priori conspire with regard to inclusion and exclusion. Other factors - ontology, paradigmatic preference, convention and ideology - are usually at work. These centre on the issue of power and who gets to legitimate meaning. In very recent post-colonial societies like South Africa, Zimbabwe and Namibia, the racial issues are always sharper than in those African societies that obtained independence half a century earlier.

My own experiences of rejection, and of how different editors enable or disable submissions, are offered as illustration of the conditions under which all authors work. ${ }^{19}$ The situations described below need to be constructively engaged, rather than disseminating conspiracies of the powerful and the racist. Early in my career, as an MA student and tutor in the late 1970s, I submitted a short article to the SAJS. It offered an Einsteinian space-time approach to the study of narrative through the application of semiological film theory. The paper was rejected, the editor told me and my supervisor, because it was not experimental, but philosophical. (Nowadays, this journal publishes commentaries, interventions and editorials, philosophy and even biographies. My timing was off by 35 years!) The article was subsequently accepted by a publication edited by my supervisor. The moment his editorial term expired, however, the still-to-be-published but accepted essay was rejected by the new editor, from the same university. Repeated requests for reviewer reports were ignored, as clearly I had been caught between two bulls in the same "kraal" (Afrikaans, "cattle enclosure').

An example of a different order involved a statistically based study submitted to Nature that attracted a blunt, unexplained rejection just three hours after submission. The study was however published as a Nature Precedings and, at last checking, had secured 305 citations. ${ }^{20}$ As with many high-impact titles (for example, Science, Current Biology, Nature), peer-review of submissions is not automatic. An editor assesses whether or not submissions are of 'sufficient interest' to the journal's wide readership. Seemingly, our topic failed these two criteria to make it into the formal journal, notwithstanding it being cited in its pre-published Precedings form. 
The second-ranked Science issued a terse rejection note for the same submission just five hours after receipt. In contrast, Psychological Science responded three months after uploading, offering very comprehensive reviewer and editor assessment. Unlike the alienation from our labour that we experienced with Nature and Science, the article was considerably enhanced by the intensive dialogical manner in which the Psychological Science editors engaged with us over two more drafts. ${ }^{21}$ According to my psychology colleagues, in addressing the difficulties of obtaining publication for studies that incorporate non-Western samples, the discipline needs to address the bias shown in its broad literature toward the study of participants located in environments unrepresentative of the majority of the global population. They point to psychology's overreliance on a narrow participant pool, and emphasise the necessity of conducting research with diverse populations. They conclude that high-impact-factor child developmental journals are heavily skewed toward publishing articles that incorporate data from WEIRD (Westernised, Educated, Industrialised, Rich and Democratic) populations. The habitual dependence on convenience sampling that lacks diversity means that culturally specific findings are being misattributed as universal traits. ${ }^{22}$

The oft-cited allegation of 'old boys clubs' or mafia-like conspiracies are diversionary, however. Understanding how academic publication works requires knowledge of publishing and peerreviewing practices across publishing cultures that uphold different scholarly conventions, peerreviewing procedures and ways of doing things.

Beyond these technicalities is the issue of paradigm clash - broadly, indeterminacies of translation - to which I now turn. Expressed differently, this clash occurs because conventional scientific systems are presumed to offer amoral codes that exist in and of themselves. African approaches, in contrast, sometimes explicitly relate moral codes to systems of both interpretation and verification. The second elaborated draft of the third iteration of this paper was emphatically accepted in 2018 by two reviewers engaged by the SAJS, but rejected by the humanities section editor on the basis of appropriate readership - better found elsewhere - while she also had some niggling issues with my African linguistics framework. (This now-published Junctures version is the fourth version.) My impression was that the SAJS editor thought that my analysis would get more traction from a different epistemological community, rather than the positivist science one to whom it was intentionally addressed. Then along came the invitation from Junctures.

The sections that follow introduce a more philosophical dimension in teasing out the question of indeterminacy.

\section{THE ISSUE OF CERTAINTY}

René Descartes was the progenitor of a whole series of attempts to overcome certain pervasive dilemmas that evolved out of the ferment of the Renaissance, the Reformation and the spread of secular literacy. ${ }^{23} \mathrm{He}$ questioned the authority of previous philosophers as he did of his own senses. The dilemmas he faced involve the ways in which power no longer emanated from hereditary European centres controlled by restricted classes or castes of literate elites. Extending the capacity to record one's own experience enables the comparison of records and, thereby, judgement. Cartesian doubt of one's lived experience offers one way of validating the latter, while also placing limits on the kinds of experience in everyday life that qualify as grounds for negatively judging encountered authority. 
The Western hereditary centres tend to label African-based (or other local) knowledge as 'different,' as 'area studies,' or even as irrelevant. Local knowledge is often insufficiently leveraged by, and lacks integration into, global theoretical discussion. This knowledge is thus impeded from actively de-stabilising conventional 'Northern' thought, defamiliarising what is taken-forgranted, and revitalising ossified paradigms rooted in positivism. My own work using self-reflexivity, autoethnography and critical indigenous qualitative methods, for example, often attracts bewildered (and sometimes vicious) peer criticism because the research teams I work with cast a critical eye as much on their own research practices as they do on their 'objects of study' and actual research outcomes. ${ }^{24}$ My team and I thus share with Sithole something of an indeterminate conceptual space, but for different reasons and under different conditions. The academy and its practices (such as peer review) are grounded in norms stemming from earlier European conventions. The medium articulates the relations of its origin.

\section{THE MIND-BODY PROBLEM 25}

The problem of Other Minds highlights logical, ontological and epistemological differences. This observation is based on modern nominalism that assumes that abstract ideas and universals have no independent existence and that they exist only as names (nominalism). ${ }^{26}$

Mind (consciousness, intelligence and so on) resides in a non-material substance that does all the thinking, resident within the human body's rather more material substantiality. This raises, of course, the (in)famous Cartesian mind-body problem. Revolutionary in its day, the logic of Descartes' separation of mental and material added much to the groundwork on which grew the Enlightenment. God's existence, the previous reasoning went, was the prime guarantor of the individual human being's capacity for rational and moral thought. Descartes enabled subsequent thinkers to pay greater attention to the role of reason in human affairs. One should not, however, confuse the freedom offered to others by the dualism of mind and matter with the potential for greater clarity in everyday life.

Perhaps the single most persistent effect of the seventeenth century's philosophical revolutions is the positivist doctrine that there exists a singularly comprehensible rational order of things accessible to human intellect, capable of being institutionalised through hereditary centres in the form of a wholly rational order of human endeavour. The conception of ideas like 'human rights,' 'national sovereignty' and the 'separation of powers' (the intellectual bases of modern political thought) is one outcome of this paradigm.

Sithole, as I read her, dismisses the Enlightenment assumption of a single human rationality in the subtitle of her book, "The politics of discourse management in the social sciences." She argues that this (hereditary) rationality is not innate, normal or natural, but is managed, mainly via North-Western impulses, where "the knowledge production field [is] trapped in the vanguard of a certain generation of peers who do not allow for diversification of discourses." She concludes that this vanguard "is also trapped in global apartheid of systems of thought that ensure that Africa applies theories and models of analysis from elsewhere." Sithole further concludes that "The NRF [National Research Foundation], the HSRC [Human Sciences Research Council] and the whole system of [South African] Higher Education continues to subscribe to an international ideological censoring machine where academic excellence is only defined by publishing in specific journals that are dominated by White males mostly from Europe and America." 27 
If Sithole is correct, then all other counter and alternative rationalities, including IKS discourses, must also be understood as similarly constructed and managed by different re-emergent hereditary constituencies, whether or not they are labelled as 'indigenous,' 'national,' or 'cultural.' Is this not the terrain on which global knowledge production is grounded? Science, like anything, is a contested terrain and what is required to negotiate differences are rules of engagement provided by the mechanisms of paradigm and paradigm shift. ${ }^{28}$ The recent emergence of critical indigenous qualitative methodologies is one productive example of such engagement that is beginning to dismantle - if currently in certain sites only - the "double absolute," where soul and body are understood as two separate substances. ${ }^{29}$

Beginning with Hobbes, ${ }^{30}$ the conviction emerged that no matter the material condition of women and men, they will follow the path of right reason once this has been revealed to them. Apartheid common sense discourse, for example, held that if its critics came to South Africa and "saw for themselves," then right reason would prevail. The method is replicated in the (counter) purpose of Sithole's book. By exposing subjugated academics to the rational (indigenous) alternative right reason, it is assumed that the force managed by the "censoring crew" ${ }^{31}$ will be discredited and the old order replaced with the new or alternative (black African) indigenous order.

However, caution is indicated. When summarily rejecting the achievements of the Enlightenment, such as occurs in many of the North-Western 'postie' approaches (post-structuralism, postmodernism, post-disciplinarity and so on), pitfalls need to be negotiated. The steady entrenchment of rights-based law and the bloody but still tangible operation of the international political sphere both derive from the Enlightenment. Without its inheritance, it is difficult to conceive of an idea like 'crimes against humanity' (of which apartheid was one) and associated international law, under which the more egregious of tyrants can be brought to some semblance of justice. The post-modern criticism of the Enlightenment is not without merit - once all the undisciplined jargon has been stripped away. The post-modern critique holds that an order based on purely rational principles cannot account for the local, personal, historical and cultural (including religious) needs and interests of ordinary people caught up in the play of these grand forces of reason. For people beyond Europe, Enlightenment reason is not always reasonable.

This is perhaps what lies at the root of Sithole's argument about the lack of 'transformation' in the South African social sciences and their global reliance on North-Western epistemologies. The signifier 'Africa,' as examined by Valentin Mudimbe ${ }^{32}$ via Michel Foucault's $\mathrm{s}^{33}$ criticism of the context of arbitration, demonstrates that the social, political and cultural differences between geopolitical imaginaries like Africa and 'the North' are a result of the historical absorption into European discourse of Descartes' dualism of mind and matter. This must follow from the institutionalisation of the dichotomy of the human and natural sciences, in which the human subject resists being an object of what Sithole interprets as the arbitrational judgement of those who hold political power over institutional (that is, publishing) controls.

IKS seems to offer a discourse responding to this particular political moment. In an often prelapsarian unreflective form, scholars collapse who they are (identity) with what they claim to know. This assumes that "minds can only communicate through bodies." ${ }^{4}$ Such knowledge is performed (through dramaturgy, oratory, identity politics) rather than mediated solely through empirically demonstrated or theoretically argued frameworks that require different kinds of communicative strategies and environments. 
IKS evokes a communal cultural memory that resides in the equivalent (but un-theorised) Jungian concept of the collective unconscious. ${ }^{35}$ For science, IKS might present itself as intuitive, an emotive and essentialist discourse in which individuals try to culturally locate themselves in dual periodised and ontological dimensions. The first is modernity, the second is an imagined, often pre-modern (anti-Western) ontological dynamical world. The result, sometimes, might be a contradictory consciousness in which a discursively fixed indigeneity prevails as public memory over the contemporary reality of a hyper-individuated, consumer-led, post-modern subjectivity. To use a stereographical metaphor, such individuals encounter both periods simultaneously, but want others to reside within (or at least recognise) their reconstruction of a different particularistic ontology deriving from a dissimilar but intersecting imagined past. In the Christian North-West, such an idealism is found in the representational form of Eden before the Fall and/or the Theory of Intelligent Design (Creationism). It may be argued that IKS, like religion and alternative medicine, require different systems of verification.

Nevertheless, questions remain:

i. what are the parameters within which particular indigenous knowledge systems can be assessed? Too often, outsiders are expected to either 'know' or accept a statement because it is a priori IKS. Outsiders from the hereditary centres need to be invited in if they are to engage constructively with such arguments and to enable paradigm shift;

ii. how to validate the results and to share them for the good of the general critical citizenry; and

iii. how to valorise in a non-essentialist manner the 'evidence of experience' claimed by self-referential researchers. ${ }^{36}$

While even critical IKS proponents tend to perform and live their approach, ${ }^{37}$ scientists conventionally require hard evidence, explicit method, objectivity and logical argument. IKS was on the agenda of the Academy of Science of South Africa (ASSAf) Consensus Study on the Humanities, on which panel I and Sithole served. ${ }^{38}$ After considerable debate, however, the topic was excluded by the panel's convenors from the final report, partly, I suspect, because the issues of indeterminacy and essentialism could not be resolved.

An illustration from the files of Critical Arts encapsulates the problem. This involved an article about female genital mutilation written by a self-declared African woman based in the NorthAtlantic region. As editor, my assessment was that the initial reviews indicated that the paper was worth developing in the context of debates on the topic, though requiring substantial revision. It lacked lucidity and awareness of the journal's readership, and was contradictory, poorly written and lacked substantiating evidence. The reviewers included a Kenyan male and a Canadian female who were researching similar issues in East and Southern Africa. Though most editors would have immediately rejected the article, the author was accorded an option for substantive revision, received the very next morning. This author rejected the reports as being part of an archaic paradigm. The lack of evidence, she said, was inconsequential as the piece was based on her own experiences as an insider. If so, we responded that she needed to rigorously problematise her research/author position through self-reflexivity and/or autoethnography, while addressing reviewer concerns. 
The third revision was judged to be unpublishable. In the author's opinion, Critical Arts had "adopted the language of academia/rigour/evidence." In contrast, as an insider, supposedly unburdened by the (seemingly conservative, archaic) practices of the academy, the author concluded (incorrectly) that the reviewers were dismissive of knowledge based solely on lived experience, rather than located "in books." For her, this African journal embodied the (Southern) gatekeeper of conventional knowledge practices.

In contrast to this experience, Critical Arts had earlier published a well-written paper arguing the merits of "female circumcision" authored by an African, male, a Nigerian, working in the United States. Our two feminist reviewers, who disagreed implacably with Frank Ukadike's ${ }^{39}$ assumptions and arguments, nevertheless concluded that the author had in a revision constructively engaged their extensive criticisms, ironically, in the process, strengthening his argument for such circumcision - described by its critics as genital mutilation. Ukadike's paper was accepted because it elaborated historical contexts and associated philosophies, and thus merited further critique. Yet, no-one to my knowledge has taken such an opportunity to engage Ukadike's arguments. This is an example where indeterminacy was applied by means of affirmative viewpoint discrimination in publishing an argument with which no-one on the Critical Arts editorial board concurred.

\section{EPISTEMOLOGICAL INDETERMINACY}

To repeat, indeterminacy refers to scientific concepts of uncertainty and is related to Kant's idea of the noumenon - that which is scientifically unknowable or explainable. ${ }^{40}$ Kant's reformulation of mind-matter dualism posited a material noumenal world, in conjunction with a world of intelligible mental objects which are phenomenal and knowable as such. But since the noumenal world is non-mental, it is unknowable. Science results from the activity of 'understanding.' Scientists thus make judgements on matters as they are relevant to these distinctions, or they express opinion: the former is to be seen as a truth-claim, the latter being of a lower order. Indeterminate "thingsin-themselves' are unquantifiable, and thus do not lend themselves to being 'tested.' This is why scientists (and lawyers) try to eliminate indeterminate terms and observations from their analyses.

The grammars of African languages arguably ascribe greater agency to the equivalents of the (sometimes radically) materialistic objects enshrined in the languages of historically industrialised nations. Their grammars have a place for qualifying an existent in terms of its subjective relatedness to the other things, persons and animals around it. Subject and Object thus become interchangeable, in much the same way as occurred in the medieval scholastic realism of premodern Europe. In thus retaining spaces for the authority of the spirits and the ancestors, for example, these grammatical syntheses also permit speakers to ascribe some measure of reality to the powerful influence of the memory of the spoken word.

It seems that some essentialist strands of the IKS paradigm are embedded in these kinds of relations. In South Africa especially, these IKS threads draw on a number of so-called a priori African values, of which the most commonly cited is ubuntu (communitarianism). ${ }^{41}$ This concept of shared lived relations is mostly discussed in the academic literature as self-evident, Africanist and contemporarily relevant. It is presented as a series of propositions, as a kind of analytical philosophy that exists in and of itself - no matter the mayhem of many of the African societies in which this idealist set of prescriptions are played out. Critiques of this framework - which assumes 
an African exceptionalism and which can result in the tyranny of the individual over the community - are few and far between. ${ }^{42}$ Nkonko Kamwangamalu's pan-African linguistic analysis stands almost alone as a basis for the concept claiming communitarian ontology. ${ }^{43}$

The existence of a plurality of ontological referents in African languages is based on the notion of $n t u$. This root word stems from the Bantu languages and connotes a sense of 'personhood,' acknowledging the humanity of the individual. Alexis Kagame ${ }^{44}$ expanded on the notion of "Being" that Placide Temples had detected in African languages. According to Temples, the Bantu conception reflects the belief that the "beings-forces" of the universe exist in a relationship in which nothing moves without influencing other forces by its movement: "The world of forces is held like a spider's web of which no single thread can be caused to vibrate without shaking the whole network." ${ }^{45}$ By using analyses and methods based on Aristotle's Physics, Kagame identified a fourlevel grid by means of which the Bantu verbal root $n t u$ could be described. Reality is ordered by Kagame into levels of influence situated between the concepts of muntu (being with intelligence), where IKS be might located, kintu (being without intelligence), hantu (location in space and time) and kuntu (roughly, modality, the way in which something happens and is experienced). ${ }^{46}$

In light of these indeterminacies, for Sithole to pursue her project, she may have to take the route she took with her book. However, she would need to argue her case dialectically in dialogue with dualistic Cartesian (kintu, where knowledge arises only though scientific method) approaches, such that she herself (kuntu) is enabled to enter into a sustained negotiation with editors (hintu) and journals to persuade them of both the value and existence of muntu (being with intelligence) and prodigality (having outgrown objectivity).

\section{PASSING THROUGH THE GATES}

Critique remains crucial, no matter the paradigm. Reducing the issue to gatekeeping, by 'White Men,' mafia editors, and racism, forgets that many of these editors have not only created spaces for different ontological perspectives in their journals, but that they are also embedded in institutional discourses and practices that to some extent circumscribe their editorial policies and publishing economies. The failure resides in the institutions whose gates they may be required to keep. Gates function as both entry and exit points. Beyond the 'gates' lie institutions that are not dependent on the race of the gatekeeper. A Black male, suggests Mboti in discussion with me, will make as good a gatekeeper as a White male, as long as the institution whose gates they keep remains unchanged and/or regulated, as occurs through the regular audits of South African journals conducted by the Academy of Science for South Africa. ${ }^{47}$ When singling out the perceived gatekeepers for special critique, we cannot see the forest for the trees, or the disease for the symptom. The gatekeeper is embedded in a variety of often determining institutional, procedural and regulatory relations that deal with the nature of science, data, ethical regimes, peer review, performance management and so on.

Publishing economies need to develop theoretical frameworks for making sense of the managerial opacity of institutions whose software systems sometimes fail to recognise the political-economic effects of measurement and reward systems that shape scientific practices and publishing economies.$^{48}$ The struggle waged in South Africa by performing and arts practitioners and scholars for recognition of their creations as 'research publications' is a case in point. ${ }^{49}$ For them, research is lived in the performance - not necessarily of the Self, but through the text and in bodily expression. 
In what way is doing a painting (knowing 'about') the same as doing/knowing/writing (doing 'that') research? Research practice can be monitored because it works according to particular conventions (mostly encoded in one kind of script or another). The transposition of words from one (epistemological) language that is radically different to another always carries a special kind of indeterminacy, because the Being (existential significance) of the referent of common nouns does not necessarily carry the same objectivity in all cultural-linguistic contexts. Meanings are observed and documented, and threaded through different kinds of sign systems, including the speaker, ontological and subject positions identified by Kagame. It is then possible to explain why interpretations by Northern (peer-) reviewers may be sometimes incomprehensible to authors located in other contexts.

Globally, world views necessarily include a high degree of indeterminacy and opacity in the way that expected interpretants will be generated. This is because there will always be one subject (for example, the scholar) seeing a "whole undissociated common sense" object, and at least one other (the subjects being reported) experiencing a dynamic relation of force, as accounted for in the experience of $n t u$. Western scientific perspectives derived from the Enlightenment and industrialism, a mode of production which is a logical consequence of Cartesian thought, assume determinateness, 'objectivity' and transparency. The second dimension incorporates indigenous frames of reference which retain Subject-Object integration (kuntu). The Western notion of 'objectivity' has little purchase among many African scholars as its 'authors' are considered (or consider themselves) to be part of the stories they tell. In post-Enlightenment thought, such a research position can be acknowledged by means of the emergent paradigm of critical indigenous qualitative methodologies that include autoethnography.

Such is the nature of paradigm engagement and shift. The Enlightenment practice of dialogue and debate offers a more productive route than simply presenting rejected articles and reviewer reports as they are, as if all issues are self-evident to all communities of readers. Reluctance to debate results in a monologue. Monologues are useful and engaging, and often entertaining, but they are undialectical. Monologues deal with the past, dialogues and dialectics address the future. Because dialogues are collective in nature, there are many minds at work. Extending the empowerment of the capacity to record one's own experience makes it possible to compare records, and to judge them. Authors, peer reviewers, readers and editors are the key constituents of this contested and discursive (if unequal) productive triangle. Epistemological progress occurs when we manoeuvre through the contradictions by keeping the conversation alive.

One outcome of humanities research is that the findings of projects are absorbed by subject communities. Thus, to test a hypothesis about some quality or aspect of communities in and on a community of scholars is in part to teach that community that such a quality or aspect offers some possible advantage to the commodiousness of their writing. In terms of research practice, academics who try to diffuse subject-generated knowledge not based on objective science, as is taken for granted by specific journals, find themselves at odds with editors. Editors - a group of subjects usually embedded in the epistemological assumptions of Western hereditary centres are thus seen by critics like Sithole to be engaging in exclusion of the dissemination of knowledge that is not-science in the ways in which they understand it. One of the requirements of authors is that they negotiate the indeterminacy, open-endedness and opacity of radical translation in eventually securing publication. 
The transposition of words from one paradigmatic language that is radically different to another always carries a special kind of indeterminacy of translation. This occurs because the Being (existential significance) of the referent of common nouns does not necessarily carry the same objectivity in all cultural-linguistic contexts. Advice given by reviewers occurs in accordance with the entirety of knowledge that they have personally accumulated over their careers. This, itself, can be influenced by the particular moods and the 'ontological space' occupied by the peer reviewer. When peer reviewers offer conflicting views it is the job of the editor or editorial coordinator to consider contending positions via Kagame's principle of prodigality and to advise authors accordingly. Sometimes, such prodigality might open up new points of discussion. Action and practitioner research should be "[p]luralistic, rather than monolithic, and diverse, rather than constrained, so that they [editors] can celebrate the unique, personal, and subjective strengths of individual research and help researchers display their own personal signatures." 50

We may all be speaking and writing in English here, but the issue is how to bridge epistemological, ontological and epistemic indeterminacy. 'Conspiracy' theories are limited in their explanatory value and they disorientate authors who hold them. Sithole has made one valiant attempt to bridge the differences. The protagonists and antagonists, however, need to engage each other dialectically in terms of epistemological issues, journal reviewing practices, the political economy of publishing and institutional research policies. These differences are not easy to resolve as science vests authority in method and theory, while IKS tends to vest the authority of knowledge within the Self, the knower. Where autoethnography is critical of the self in relation to that being lived and experienced, some approaches to IKS do not lend themselves to scientific testing or dialectical debate. This is a substantive issue that still needs attention in terms that get beyond claims of conspiracy on the part of (some) editorial boards.

\section{ACKNOWLEDGEMENTS}

My thanks go to Menán du Plessis, Thad Metz and Nyasha Moboti for their helpful comments on earlier drafts.

Keyan Tomaselli is Distinguished Professor, Department of Communication, University of Johannesburg and a member of the Academy of Science for South Africa. He is Honorary Professor in the Centre for Trans-media and Trans-culture, Capital Normal University, Beijing. 
1. Adam Habib, Rebels and Rage: Reflecting on \#Feesmustfall (Cape Town: Jonathan Ball, 2019). Also see Susan Booysen (ed.), Fees Must Fall: Decolonisation and Governance in South Africa (Johannesburg: Witwatersrand University Press, 2016).

2. This definition of indigeneity was developed in conjunction with the Leeds University Institute for Colonial and Postcolonial Studies and elaborated on in my work on cultural tourism in Southern Africa among indigenous communities. See Keyan G Tomaselli, Cultural Tourism and Identity: Rethinking Indigeneity (Leiden: Brill, 2012), 47-51.

3. Miranda Fricker, Epistemic Injustice: Power and the Ethics of Knowing (Oxford: Oxford University Press, 2007). See also Savo Heleta, “Decolonisation of Higher Education: Dismantling Epistemic Violence and Eurocentrism in South Africa," Transformation in Higher Education, 1:1 (2016), https://thejournal.org.za/index.php/thejournal/ article/\%20view/9\%20/31; also Siseko H Kumalo, "Defining an African Vocabulary for the Exploration of Possibilities in Higher Education," Alternation (special edition), 23 (2018), 197-223, https://doi. org/10.29086/2519-5476/2018/sp23a9

4. Jonathan Jansen, "Black Professors: What it will Take to Produce More," BizNews, 11 June 2015, https://www.biznews.com/thoughtleaders/2015/06/11/black-professors-what-itwill-take-to-produce-more-of-them

5. N Mkhize, “'Transform' Means to Add to a Course, not Erase it," BusinessLive, 11 August 2015, https://www.businesslive.co.za/archive/2015-0811-transform-means-add-to-a-course-not-erase-it/

6. Belinda Bozzoli, "The Looming Crisis in Academia," Politicsweb, 27 August 2015, http://www. politicsweb.co.za/news-and-analysis/the-loomingcrisis-in-academia

7. Zimitri Erasmus, Race Otherwise: Forging a New Humanism for South Africa (Johannesburg: Witwatersrand University Press, 2017).

8. M Pearl Sithole, "The Struggle of Critical Scholarship," ANFASA (Academic and Non-fiction Authors' Association of South Africa) Newsletter, 1:2 (2008), 3-4; see also Elizabeth Le Roux, "Discriminatory Practices in Scholarly Publishing," Critical Arts, 29:6 (2015), 702-3, https://doi.org/1 0.1080/02560046.2015.1151104

9. Anthea Jeffrey, "The Fight against Racism should be Colour-blind," Mail \& Guardian, 25-31 August 2001, 30.

10. M P Sithole, Unequal Peers: The Politics of Discourse Management in the Social Sciences (Pretoria: Africa Institute of South Africa, 2009) (back cover).
11. Ibid. 12.

12. Sylvester C Chima, Takafira Mduluza and Julius Kipkemboi, "Viewpoint Discrimination and Contestation of Ideas on its Merits, Leadership and Organizational Ethics: Expanding the African Bioethics Agenda," BMC Medical Ethics, 14 (Suppl. 1) (2013), https://doi.org/10.1186/1472-693914-S1-S1

13. Joseph Henrich, Steven J Heine and Ara Norenzayan, "The Weirdest People in the World?" Behavioral and Brain Sciences, 33:23 (2012), 61-83, https://doi.org/10.1017/ s0140525X0999152X

14. Willard V O Quine, Ontological Relativity and Other Essays (New York: Columbia University Press, 1969).

15. Cited in Keyan G Tomaselli, "Practices in Scholarly Publishing: Making Sense of Rejection," Critical Arts, 29:6 (2015), 712-24, https://doi.org/10.1 080/02560046.2015.1151107. The argument presented here, however, is greatly elaborated.

16. Charles Sanders Peirce, The Collected Papers of Charles Sanders Peirce, eds. C Hartshorne, P Weiss (vols. 1-6) and A Burks (vols. 7-8) (Cambridge, MA: Harvard University Press, 1931-58 and 1960-66), 6.580 and 8.184 .

17. Norman Denzin, "The Death of Data?" Cultural Studies $\leftrightarrow$ Critical Methodologies, 13:4 (2013), 353-6.

18. Nyasha Mboti, "Research, Method and Position: What are we Doing?" in Cultural Tourism and Identity: Rethinking Indigeneity, ed. K G Tomaselli (Leiden: Brill, 2012), 53-70, https://doi. org/10.1163/9789004234581_005

19. See also Paul J da Silva, How to Write a Lot (Washington, DC: American Psychological Association, 2007).

20. Mark Nielsen and Keyan Tomaselli, "Over-imitation in the Kalahari Desert and the Origins of Human Cultural Cognition," available from Nature Precedings (2009), http://hdl.handle.net/10101/ npre.2009.3049.1

21. M Nielsen and K G Tomaselli, "Overimitation in Kalahari Bushman Children and the Origins of Human Cultural Cognition," Psychological Science, 21:5 (2010), 1-8. http://journals.sagepub.com/ doi/abs/10.1177/0956797610368808

22. Mark Nielsen, Daniel Haun, Joscha Kärtner and Cristine H Legare, "The Persistent Sampling Bias in Developmental Psychology: A Call to Action," Journal of Experimental Child Psychology, 162 (2017), 31-8. See also Henrich et al., "The Weirdest People in the World?"

23. Rene A Descartes, Discourse on Method (London: Dent, 1969). 
24. For a polite critique of my team's autoethnographic work see, e.g., Megan Biesele and Robert $\mathrm{K}$ Hitchcock, "Writing in the San/d Auto-ethnography among Indigenous Southern Africans (review)," Collaborative Anthropologies, 1:1 (2008), 2015, https://doi.org/10.1353/cla.0.0008, and my equally polite reply, K G Tomaselli, “Visualizing Different Kinds of Writing: Auto-ethnography, Social Science," Visual Anthropology, 26:2 (2013), 165-80.

25. This paraphrase and some other sections draw on Arnold Shepperson's unpublished "Thinking Aloud" notes that were collated after his death and from which a special issue of Critical Arts 22:2 (2008) was edited.

26. Gilbert Ryle, The Concept of Mind (Harmondsworth, UK: Peregrine, 1963).

27. Sithole, Unequal Peers.

28. Thomas S Kuhn, The Structure of Scientific Revolutions (Chicago: University of Chicago Press, 1970).

29. Peirce, Collected Papers, 6.580.

30. T Hobbes, Leviathan, ed. Noel Malcolm (Oxford: Oxford University Press, 2014 (1651)).

31. Sithole, "The Struggle of Critical Scholarship."

32. Valentin Y Mudimbe, The Invention of Africa: Gnosis, Philosophy and the Order of Knowledge (Bloomington: Indiana University Press, 1989).

33. Michel Foucault, The Order of Things (London: Routledge, 1974).

34. Peirce, Collected Papers, 6.580.

35. Carl Jung, "The Concept of the Collective Unconscious," https://pdfs. semanticscholar.org/a9f3/0fd0edb9a dfd 1e 1 dfc 4 e 1 a 6 ac 76 fd 6 cfa 8 ee.pdf? ga $=2.108097922 .1815067822 .1562232664$ 1015715016.1562232664

36. Keith Berry and, Robin P Clair, "Contestation and Opportunity in Reflexivity: An Introduction," Cultural Studies $\leftrightarrow$ Critical Methodologies, 11:2 (2011), 957, https://doi.org/10.1177/1532708611401326

37. Handel K Wright, “Editorial: Whose Diaspora is this Anyway? Continental Africans Trying on and Troubling Diasporic Identity," Critical Arts, 17:1-2 (2003), 1-16, https://doi. org/10.1080/02560240385310021

38. Academy of Science of South Africa (ASSAf), Consensus Study on the State of the Humanities in South Africa: Status, Prospects and Strategies (Pretoria: ASSAf, 2011), https:// www.assaf.org.za/files/2011/09/2011Humanity-final-proof-11-August-2011.pdf
39. Frank N Ukadike, "African Films: A Retrospective and a Vision for the Future," Critical Arts, 7:1 (1993), 43-60, https://doi. org/10.1080/02560049385310041

40. Immanuel Kant, Immanuel Kant's Critique of Pure Reason (Basingstoke, UK: Palgrave, 1989). For a specific discussion of the noumenal, see T I Oizerman, "Kant's Doctrine of the 'Things in Themselves' and Noumena," Philosophy and Phenomenological Research, 41:3 (1981), 33350, https://www.jstor.org/stable/2107456?origi $\mathrm{n}=$ crossref\&seq=2\#metadata_info_tab_contents

41. See, e.g., Leyla T Tavernaro-Haidarian, A Relational Model of Public Discourse: The African Philosophy of Ubuntu (London: Routledge, 2018).

42. For critiques of ubuntu as a legitimating strategy, see Ngaire Blankenberg, "In Search of a Real Freedom: Ubuntu and the Media," Critical Arts, 13:2 (1999), 42-65; and Keyan G Tomaselli, "Ubuntu and Intercultural Communication: Power, Inclusion and Exclusion," Intercultural Communication Studies, 25:2 (2017), 1-13, http://web.uri.edu/iaics/2016-vol-25-no-2/

43. Nkonko M Kamwangamalu, "Ubuntu in South Africa: A Sociolinguistic Perspective to a PanAfrican Concept," Critical Arts, 13:2 (1999), 24-41.

44. Alexis Kagame, La philosophie Bantu-rwandiase de l'étre (Brussels: Académie Royale des Sciences Coloniales, 1956).

45. Placide Temples, Bantu Philosophy (Paris: Presence Africaine, 1959), 28, http://www.congoforum.be/ upldocs/Tempels $\% 20$ BantuPhil\%20English $\% 20$ 1959.pdf

46. See also Nelson Udoka Ukwamedua, “A Critical Review of Alexis Kagame's Four Categories of African Philosophy," Origisi: A New Journal of African Studies, 8 (2011), 248-56, http://dx.doi. org/10.4314/og.v8i1.13

47. See "ASSAf Peer Review of Accredited Journals," http://assafjournalblog.org.za/assaf-peer-reviewof-accredited-journals/

48. Keyan G Tomaselli, "Perverse Incentives and the Political Economy of South African Academic Journal Publishing," South African Journal of Science, 114:11-12 (2018), 1-6, https://doi. org/10.17159/sajs.2018/4341

49. Temple Hauptfleisch, "Artistic Output, Arts Research and the Rating of the Theatre Practitioner as Researcher - Some Responses to the NRF Rating System after the First Three Years," South African Theatre Journal, 19:1 (2005), 9-34, https://doi.org/10.1080/10137548.2005.9687 799; Liz Mills, "A Conversation that is Research," South African Theatre Journal, 19:1 (2005), 35- 
42, https://doi.org/10.1080/10137548.2005.96 87800; and Millie Taylor, “Schrödinger's Research: When does Practice as Research Occur?" South African Theatre Journal, 91:1 (2005), 183-90, https://doi.org/10.1080/10137548.2005.9687 810
50. Pamelia Lomax and Zoe Parker, "Accounting for Ourselves: The Problematic of Representing Action Research," Cambridge Journal of Education, 24:3 (1995), 301-14, https://doi. org/10.1080/0305764950250303 